\title{
Striatal Information Signaling and Integration in Globus Pallidus: Timing Matters
}

\author{
C. Savio Chan ${ }^{a, b}$ D. James Surmeier ${ }^{a}$ Wing-Ho Yung ${ }^{b}$ \\ a Department of Physiology and Institute for Neuroscience, Northwestern University Feinberg School of Medicine, \\ Chicago, III., USA; ${ }^{b}$ Department of Physiology, Chinese University of Hong Kong, Hong Kong, SAR, China
}

\section{Key Words}

Gamma-aminobutyric acid · Basal ganglia $\cdot$ Caudate putamen · Dendrites $\cdot$ Local collaterals $\cdot$ Parkinson's disease $\cdot$ Pauses, globus pallidus neuron activity · Synaptology $\cdot$ Synchrony, globus pallidus neuron discharges

\begin{abstract}
Advances in research on globus pallidus (GP) suggest that this 'long thought to be' relay in the 'indirect pathway' plays a unique and critical role in basal ganglia function. The traditional idea of parallel processing within the basal ganglia is also challenged by recent findings. It is now clear that axons of GP neurons form large, perisomatic baskets around target neurons in all major basal ganglia nuclei, thereby exerting a profound influence on the output of the entire basal ganglia. GP neurons are autonomously active both in vivo and in vitro. It is believed that temporal information carried along the corticostriatopallidal pathway is critical for proper motor execution. The importance of appropriately controlled discharge of GP neurons is highlighted by psychomotor disorders such as Parkinson's disease, in which alterations in the pattern and synchrony of discharge in GP
\end{abstract}

neurons are thought to contribute to motor symptoms. Several lines of evidence suggest that the aberrant activity of GP neurons following dopamine depletion is caused by alteration in the synaptic input from both striatum and subthalamic nucleus. In normal subjects, the capability of striatal input in translating cortical input into precisely timed responses in GP neurons is mediated by (1) the expression of postsynaptic $\mathrm{GABA}_{\mathrm{A}}$ receptor composed of subunits with fast kinetic properties; (2) an effective GABA reuptake system in terminating the action of synaptically released GABA, and (3) the existence of dendritic $\mathrm{HCN}$ channels that actively abbreviate the time course of the inhibitory postsynaptic potentials and reset rhythmic discharge. Despite the rapid pace in uncovering the elements that shape the activity along the striatopallidosubthalamic pathway, the origin of rhythmic, synchronized bursting of GP neurons seen in parkinsonism has not been fully established experimentally. Further elucidation of the factors that control the information transfer in the striatopallidal synapses is thus critical to our understanding of basal ganglia function and establishing treatment for Parkinson's disease and other basal ganglia disorders.

Copyright $@ 2005$ S. Karger AG, Basel

\section{KARGER}

Fax +4161306 1234 E-Mail karger@karger.ch www.karger.com
(C) 2005 S. Karger AG, Basel

1424-862X/05/0146-0281\$22.00/0

Accessible online at:

www.karger.com/nsg
Dr. Wing-Ho Yung

Department of Physiology, Chinese University of Hong Kong

Shatin, New Territories

Hong Kong, SAR (China)

Tel. +852 2609 6880, Fax +852 2603 5022, E-Mail whyung@cuhk.edu.hk 


\section{Introduction}

Over the past few years, there have been several reviews that have summarized advances in various aspects of basal ganglia research. Most of these reviews have focused on midbrain dopaminergic neurons - which degenerate in Parkinson's disease (PD) - or their principal target: the striatum. These reviews have not provided an overview of recent studies suggesting that the globus pallidus (GP) plays a unique role in basal ganglia function. In particular, studies that examined the striatopallidal synapse have suggested that this synapse conveys temporal information necessary for proper motor execution. There also is compelling evidence suggesting that dysfunction of the GP constitutes a central origin of psychomotor disorders, including PD, where there is an alteration in pattern and synchrony of discharge of GP neurons. This review will summarize our current understanding of the GP, focusing on GABAergic signaling mechanisms and their relationship in basal ganglia dysfunction.

\section{The GP Is a Critical Player in the Basal Ganglia}

The rodent GP - and its primate equivalent, the external segment of the GP (GPe) - has traditionally been viewed as a mere 'relay' in the 'indirect pathway' [1-4]. However, recent anatomical and electrophysiological studies have shown that the GP is richly interconnected with all other major elements in the basal ganglia macrocircuit [5-13]. GP neurons form large, perisomatic baskets around their target neurons, much like those formed by the 'baskets cells' in cortex, hippocampus, and cerebellum [12, 14-17]. Unlike interneurons, which only innervate the local, principal neurons, the axon of a single GP neuron can travel for a very long distance, innervating neurochemically and functionally diverse neuronal types [10, 12, 13, 18, 19]. This broad range of connectivity as well as the perisomatic targeting of their synapses suggest that the GP neuron activity can exert a profound influence on global basal ganglia function.

\section{Cell Types and Synaptic Inputs in the GP}

Morphological and electrophysiological studies performed in rodents and primates are in agreement that there is one predominant cell type within the GP [11,
20-25]. These GP neurons express GAD67 and parvalbumin, have discoidally arborizing dendrites, and project an axon to the subthalamic nucleus (STN) [7-9, 18, 2629]. This population of GP neurons is intermixed with ENK-expressing GABAergic neurons that predominantly project back to the striatum $[7,28-30]$. The observed heterogeneity of cellular makeup within the confine of the GP in part is due to a displaced population of basal forebrain cholinergic neurons near the medioventral portion of the GP [27, 31-33]. However, there is no evidence that the properties of GP neurons are discrete, nor is there a definitive correlation between electrophysiological properties and morphological and molecular features of GP neurons. There are suggestions that the properties of GP neurons are overlapping and highly depend on threshold and sensitivity of the assays.

The principal excitatory input to the GP arises from the STN, but it accounts for less than $10 \%$ of synapses impinging onto GP neurons. This excitatory input mediates transmission via synaptically localized AMPA and NMDA ionotropic receptors positioned on the long dendrites of GP neurons (up to $1 \mathrm{~mm}$ in rodents and $1.6 \mathrm{~mm}$ in macaques) [34].

In contrast, the majority ( $\sim 80-90 \%)$ of the synaptic input to GP neurons is derived from the dorsal striatum. Approximately two thirds of these arise from enkephalinergic, dopamine $\mathrm{D}_{2}$ receptor expressing medium spiny neurons. The remainder originates from collaterals of striatonigral (substance $\mathrm{P}$ and dopamine $\mathrm{D}_{1}$ receptor expressing) neurons [35-37]. This rich GABAergic input primarily targets the dendrites of GP neurons, as first suggested by Golgi staining and immunohistochemistry that showed the 'woolly' fiber structures of pallidal dendrites enmeshed by a plexus of thin, enkephalin- or substanceP-positive putative striatal axons [19, 38-46]. Ultrastructural studies further revealed that dendrites of GP neurons are fully covered by a mosaic of symmetrical synapses. These findings are consistent with the notion that the striatopallidal afferents have a feature that is homologous to that formed between climbing fiber and cerebellar Purkinje neurons [14, 47-49]. Single-axon labeling studies $[26,36,40,50]$ demonstrated that the striatal axon ramifies into branches that ensheath dendrites of pallidal neurons - a morphology characteristic resembling 'woolly' fiber. However, theses studies also showed that a single striatal axon only forms a relatively small number (100-250 in both rats and macaques) and a low density (10/100 $\mu \mathrm{m}^{2}$ in macaques) of synapses within the confine of GP. In fact, single striatal axons form only a few synapses on individual dendrites of GP neurons. In- 
stead, they often contact several pallidal dendrites successively [26, 36, 50-52].

The striatal input to GP is highly convergent. In the rat, there are roughly 3 million striatal neurons, but only 46,000 GP neurons [53]. Assuming all of the neurons in the striatum are pallidal projecting, individual GP neurons should receive input from about 60 medium spiny neurons. The dendritic arbor of GP neurons (with a receptive surface estimated to be $\sim 30,000 \mu \mathrm{m}^{2}$ in macaques) is oriented perpendicularly to the incoming, radial striatal fibers, creating an ideal anatomical arrangement for intercepting axons from broad striatal regions $[13,26,36,40,54,55]$.

In addition to the striatal input, intrapallidal collaterals account for another major source of GABAergic input onto GP neurons. Juxtacellular labeling or intracellular dye loading of GP neurons has revealed the presence of numerous varicosities of various sizes within the dendritic field of parent neurons. Nearly all principal GP neurons have local axon collaterals that terminate on somata and proximal dendrites of their neighboring neurons $[8,11-13,23,56]$. However, very little is known about the properties of this connection.

\section{GP Activity Patterns}

In awake animals, GP neurons maintain a high rate of ambient spiking [22, 57-62]. This tonic 'background' activity was originally thought to be dependent upon excitatory synaptic input arising from the STN $[2,63]$. However, it is now recognized that neurons within the GP are autonomously active $[20,21,27,64,65]$. Thus, discharge rate and pattern seen in vivo likely reflect the interaction between intrinsic and extrinsic synaptic influences [24, 66-68].

Recordings from primate GPe suggest that a phasic neuronal activity is important for generating movement sequences. Transient pauses in GP activity are thought to terminate sustained neuronal activity in the supplementary motor area and to allow the next movement in the sequence to be executed [69]. These pauses or reductions in the activity of GP neurons are likely to be evoked by a striatal or perhaps intrapallidal GABAergic input. Electrical stimulation of various cortical areas (prefrontal, premotor, supplementary motor, and arcuate premotor areas and motor cortex) and striatum inhibits spontaneous discharge of pallidal neurons [60, 61] - an effect that is blocked by local infusion of a $\mathrm{GABA}_{\mathrm{A}}$ receptor antagonist into the GP [66, 70]. In addition, electrical stimulation of the striatum produces cortical and behavioral responses identical to those achieved by direct stimulation of the GPe alone [71]. These observations are supplemented by in vitro studies, showing that pauses in the activity of GP neurons can be produced by a GABAergic synaptic input arising from the striatum [11, $20,56,64,66,72]$.

\section{Sculpting GABAergic Signaling at the Striatopallidal Synapse}

If the timing of striatally induced pauses in GP activity is critical to movement, then the GABAergic striatopallidal synapse must be capable of faithfully translating striatal activity into precisely timed postsynaptic events. Although much remains to be done in characterizing this synapse, recent work has revealed key features of its operation.

\section{Biophysical Properties of the Striatopallidal Synapse}

Striatal stimulation evokes long-latency (4-8 $\mathrm{ms}$ in mice and 5-10 ms in rats), inhibitory postsynaptic potentials (IPSPs) in GP neurons with reversal potential close to the predicted equilibrium potential for $\mathrm{Cl}^{-}[56,73-76]$. The slow conduction velocity has been noted in rats $(0.8 \mathrm{~m} / \mathrm{s})$ [56], in guinea pigs $(0.33 \mathrm{~m} / \mathrm{s})$ [20], and in primates $[60,61]$. The responses typically display pairedpulse facilitation [73-76], indicative of a relatively low release probability of the synapse [77]. IPSPs are blocked by $\mathrm{GABA}_{\mathrm{A}}$ receptor antagonists, e.g., bicuculline and SR95531/gabazine. Thus, as predicted by morphological study (symmetrical and high contents of GAD, GABA), the striatopallidal synapse uses GABA [19].

Miniature inhibitory postsynaptic currents (mIPSCs), recorded in the presence of TTX and ionotropic glutamate receptor blockers, can often be separated into two subclasses. The majority of mIPSCs are small in amplitude and have variable time courses. Despite such variability, the rise and decay kinetics of individual mIPSCs are positively correlated. The variability in MIPSC kinetics is consistent with the convergence of many different striatopallidal terminals on a single pallidal neuron and the broad dendritic distribution of these synapses.

In contrast, the large, kinetically fast mIPSCs most likely arise from proximal synapses formed by recurrent collaterals of GP neurons [8, 11-13, 23, 56]. In support of this view, large and regularly spaced IPSCs that are TTX sensitive can be seen in voltage clamp recordings from GP neurons. Although these recurrent synapses 
are of clear importance to our understanding of GP circuit dynamics [78], very little is known about them because of the difficulty in selectively isolating these collaterals.

\section{Postsynaptic $G A B A_{A}$ Receptors}

$\mathrm{GABA}_{\mathrm{A}}$ receptors are ligand-gated $\mathrm{Cl}^{-}$channels. Eight subunit classes have been isolated to date $(\alpha 1-6, \beta 1-4$, $\gamma 1-3, \delta, \varepsilon, \pi, \theta$, and $\rho 1-3)$. It is thought that most functional $\mathrm{GABA}_{\mathrm{A}}$ receptors in vivo are formed by coassembly of two $\alpha$ - and two $\beta$-subunits and additional subunits [79-86], As revealed by a number of approaches, the $\mathrm{GABA}_{\mathrm{A}} \alpha 1$ subunit is expressed at very high levels in the GP [87-93]. The $\mathrm{GABA}_{\mathrm{A}} \alpha 1$ subunit is often found at synapses with fast synaptic currents which are at least in part attributable to fast desensitization [94-96]. Immunocytochemical studies have shown that the striatopallidal synapses are richly invested with $\alpha 1$ subunits [97, 98]. In accord with this finding, zolpidem, a $\mathrm{GABA}_{\mathrm{A}} \alpha 1$ subunit selective imidazopyirine agonist, slows the decay kinetics of striatal mIPSCs in the GP, leaving their frequency and amplitude unchanged. Zolpidem has a stronger impact on striatopallidal IPSCs than on those arising from local collaterals. In mice with genetic deletions of the $\mathrm{GABA}_{\mathrm{A}} \alpha 1$ subunit, there is a profound loss of $\mathrm{GABA}_{\mathrm{A}}$ receptors in the GP, and they exhibit tremor [99]. The linkage of this subunit to PD has been strengthened by the downregulation of GP GABA $A$ A 1 subunits in PD patients and models and the therapeutic effectiveness of zolpidem (see below).

\section{GABA Transporters}

Three GABA transporters have been identified in the brain. GABA transporter subtype 1 (GAT1) is predominantly found in axons, presynaptic terminals, and glial cells. GAT2 is weakly expressed throughout the brain, primarily in arachnoid and ependymal cells. GAT3 is found predominantly on glial cells [100-109]. High levels of mRNAs and proteins for GABA transporters GAT1 and GAT3 have been found in the GP. Moderate levels of mRNA for GAT1 are also found in the striatum [105107, 110-114]. Consistent with this, systemic administration of the GAT1 antagonist tiagabine increases the extracellular level of GABA [115]. Interestingly, GAT1 knockout mice, like the $\mathrm{GABA}_{\mathrm{A}} \alpha 1$ subunit knockout mice, exhibit tremors [116].

In acutely prepared tissue slices, tiagabine slows the decay kinetics of GP mIPSCs in much the same way as zolpidem [117]. Presumably, blockade of the GABA uptake via GAT1 increases the concentration of GABA at the synaptic cleft, leading to prolonged activation of postsynaptic $\mathrm{GABA}_{\mathrm{A}}$ receptors on GP neurons. In addition, activation of presynaptic $\mathrm{GABA}_{\mathrm{B}}$ receptors at the striatopallidal terminals is tightly controlled by GAT1, as the application of tiagabine significantly reduces the frequency of mIPSCs in a CGP55845-sensitive manner. Electron microscopy analysis has shown that GAT1 is predominantly localized in axonal segments and glial juxtaposed at symmetrical synapses. GAT3 is found exclusively on glial processes in the GP $[111,118]$ that ensheath dendrites and terminals. Better characterizing the role of GABA transporters in shaping GABA transmission will be crucial to our understanding of GP and the development of better therapeutic strategies for movement disorders.

\section{HCN Channels Abbreviate the Time Course of IPSPS} and Mediate Synaptic Resetting

Single-cell RT-PCR and immunohistochemical approaches revealed robust expression of $\mathrm{HCN} 2$ subunits, as well as significant levels of HCN1 subunits, in GABAergic GP neurons [27, 119]. These voltage-gated channels unlike most others are activated by hyperpolarization and have a reversal potential of about -20 to $-30 \mathrm{mV}$. The admixture of HCN1 channels with HCN2 (the predominant channel type) gives rise to a channel with a faster activation kinetics and a more depolarized voltage of activation. Transient incoming striatal GABAergic input efficiently recruits the dendritic $\mathrm{HCN}$ channels. This in turn generates inward currents (depolarization) that abbreviate the duration of the IPSPs, leading to resetting of rhythmic discharge [27]. In this way, the temporally correlated striatopallidal activity would be capable of inducing phase synchrony among a subpopulation of GP neurons. This integrative feature of GP neurons is likely to be important to both the phasic changes in activity seen during voluntary movement as well as the emergence of correlated, rhythmic bursting seen in PD models.

\section{Contribution of GP Dysfunction to the Symptoms of PD}

In contrast to the activity patterns seen in normal animals and humans, correlated, rhythmic burst discharge of GP neurons emerges in PD [62, 120-129]. This abnormal activity pattern is thought to be closely linked to rigidity and tremor [130], as well as dyskinesias [121, 123, 125]. Disruption of this aberrant activity pattern with 
electrical stimulation alleviates PD symptoms, strengthening the causal linkage in PD [131].

The origin of rhythmic bursting in GP neurons has not been fully established experimentally. Using organotypic cultures, Plenz and Kital [132] reported that STN and GP could form a reciprocally connected oscillatory network. But the critical cellular and molecular determinants of this network have yet to be defined. At present, we have only fragmentary data. Bevan et al. [133] have shown that low-threshold, T-type (Cav3) $\mathrm{Ca}^{2+}$ channels in STN neurons create a post-IPSPs burst of activity. This burst could induce an elevation in GP activity by virtue of the glutamatergic projection from the STN. But it is not clear how the pauses in GP activity arise. Modeling work suggests that both recurrent collateral GABAergic connections and striatal GABAergic input are important to the emergence of rhythmic bursting [78]. There are several lines of evidence implicating altered GABA transmission at striatopallidal synapses in PD. Injection of the $\mathrm{GABA}_{\mathrm{A}}$ receptor antagonist bicuculline directly into the GP had marked antiparkinsonian effects and increased the locomotor score in a reserpine-treated rodent model of PD [134]. However, local injection of this antagonist into the GPe in normal monkeys induced abnormal posture and contraction [135], dyskinesias [58], or even akinesias [136]. Furthermore, tremor was observed in $\mathrm{GABA}_{\mathrm{A}} \alpha 1$ subunit and GAT1 knockout mice [99, 116]. An important feature of dopamine depletion is the dramatic enlargement in striatopallidal terminals (up to 90\%) and the increased GABA synthesis in striatopallidal neurons at the GP level [124, 137-140]. Consistent with an enhanced release of GABA from striatopallidal terminals, the total number of GP GABA $\mathrm{A}_{\mathrm{A}}$ receptors decreases after a nigrostriatal lesion [141-145]. This is attributed to the downregulation of the $\alpha 1$-subunit-containing $\mathrm{GABA}_{\mathrm{A}}$ receptors $[146,147]$. Yet, the overall response to striatal stimulation increases following dopamine depletion. At this point, it is not clear whether there are changes in the composition or in the density of $\mathrm{GABA}_{\mathrm{A}}$ receptors localized at these synapses. Why these adaptations occur is not clear. The traditional model argues that the striatopallidal activity increases following dopamine depletion $[4,148$ 151]. However, recent work by our group has shown that striatopallidal neurons undergo a profound deafferentation following dopamine depletion. In isolation, this would lead to a diminished striatopallidal activity. In simulations of the basal ganglia network reported by Terman et al. [78], any significant change in the striatopallidal activity (in either direction) could induce rhythmic bursting.

\section{Conclusions}

Although the static 'box-and-arrow' model of the basal ganglia $[3,4]$ has been of great heuristic value, it clearly does not capture the dynamic properties we know to be critical. It also fails to account for function and importance of the internuclear connectivity of the basal ganglia. These deficiencies are particularly prominent when thinking about the GP. We now know that GP neurons form multiple projections to virtually all major components of the basal ganglia. This challenges the view of sequential, parallel processing within the basal ganglia and argues that GP is not simply a sign inverter in the indirect pathway. These neurons are autonomously active and generate patterns of activity that are critical to basal ganglia function and movement execution. More and more, we are coming to the view that the pattern of activity, rather than the mean rate, is what is important in both health and disease. Our understanding of how synaptic and intrinsic properties of GP neurons shape these activity patterns is rapidly advancing, but much remains to be done.

\section{Acknowledgments}

This work was supported by the Morris K. Udall Parkinson's Disease Research Center of Excellence (National Institute of Neurological Disorders and Stroke Grant P50 NS047085) and the Research Grants Council of Hong Kong (Grant CUHK 4175/02M). We thank Drs. Wendy Wu and David Carr for their thoughtful discussion and critical reading of the manuscript. 


\section{References}

1 Joel D, Weiner I: The connections of the primate subthalamic nucleus: indirect pathways and the open-interconnected scheme of basal ganglia-thalamocortical circuitry. Brain Res Brain Res Rev 1997;23:62-78.

-2 Parent A, Hazrati LN: Functional anatomy of the basal ganglia. II. The place of subthalamic nucleus and external pallidum in basal ganglia circuitry. Brain Res Brain Res Rev 1995;20: 128-154.

3 Alexander GE, Crutcher MD: Functional architecture of basal ganglia circuits: neural substrates of parallel processing. Trends Neurosci 1990;13:266-271.

4 Albin RL, Young AB, Penney JB: The functional anatomy of basal ganglia disorders. Trends Neurosci 1989;12:366-375.

-5 Walker RH, Arbuthnott GW, Wright AK: Electrophysiological and anatomical observations concerning the pallidostriatal pathway in the rat. Exp Brain Res 1989;74:303-310.

-6 DiFiglia M, Aronin N, Martin JB: Light and electron microscopic localization of immunoreactive Leu-enkephalin in the monkey basal ganglia. J Neurosci 1982;2:303-320.

7 Kita H, Kita T: Number, origins, and chemical types of rat pallidostriatal projection neurons. J Comp Neurol 2001;437:438-448.

8 Kita H, Kitai ST: The morphology of globus pallidus projection neurons in the rat: an intracellular staining study. Brain Res 1994;636: 308-319.

-9 Kita H: Parvalbumin-immunopositive neurons in rat globus pallidus: a light and electron microscopic study. Brain Res 1994;657:3141.

10 Kita H, Tokuno H, Nambu A: Monkey globus pallidus external segment neurons projecting to the neostriatum. Neuroreport 1999; 10: 1467-1472.

-11 Nambu A, Llinas R: Morphology of globus pallidus neurons: its correlation with electrophysiology in guinea pig brain slices. J Comp Neurol 1997;377:85-94.

-12 Bevan MD, Booth PA, Eaton SA, Bolam JP: Selective innervation of neostriatal interneurons by a subclass of neuron in the globus pallidus of the rat. J Neurosci 1998;18:94389452.

13 Sato F, Lavallee P, Levesque M, Parent A: Single-axon tracing study of neurons of the external segment of the globus pallidus in primate. J Comp Neurol 2000;417:17-31.

14 Palay S, Chan-Palay V: Cerebellar Cortex: $\mathrm{Cy}-$ tology and Organization. New York, Springer, 1974.

$\checkmark 15$ Bevan MD, Clarke NP, Bolam JP: Synaptic integration of functionally diverse pallidal information in the entopeduncular nucleus and subthalamic nucleus in the rat. $\mathrm{J}$ Neurosci 1997; 17:308-324.

16 Markram H, Toledo-Rodriguez M, Wang Y, Gupta A, Silberberg G, Wu C: Interneurons of the neocortical inhibitory system. Nat Rev Neurosci 2004;5:793-807.
17 McBain CJ, Fisahn A: Interneurons unbound. Nat Rev Neurosci 2001;2:11-23.

18 Parent A, Sato F, Wu Y, Gauthier J, Levesque M, Parent M: Organization of the basal ganglia: the importance of axonal collateralization. Trends Neurosci 2000;23(10 Suppl):S20-S27.

19 Smith Y, Bevan MD, Shink E, Bolam JP: Microcircuitry of the direct and indirect pathways of the basal ganglia. Neuroscience 1998; 86 : 353-387.

20 Nambu A, Llinas R: Electrophysiology of globus pallidus neurons in vitro. J Neurophysiol 1994;72:1127-1139.

21 Cooper AJ, Stanford IM: Electrophysiological and morphological characteristics of three subtypes of rat globus pallidus neurone in vitro. $\mathrm{J}$ Physiol 2000;527(Pt 2):291-304.

22 DeLong MR: Activity of pallidal neurons during movement. J Neurophysiol 1971;34:414427.

23 Difiglia M, Pasik P, Pasik T: A Golgi and ultrastructural study of the monkey globus pallidus. J Comp Neurol 1982;212:53-75.

24 Bergstrom DA, Walters JR: Neuronal responses of the globus pallidus to systemic administration of $d$-amphetamine: investigation of the involvement of dopamine, norepinephrine, and serotonin. J Neurosci 1981;1:292-299.

25 Iwahori N, Mizuno N: A Golgi study on the globus pallidus of the mouse. J Comp Neurol 1981;197:29-43.

26 Yelnik J, Francois C, Percheron G: Spatial relationships between striatal axonal endings and pallidal neurons in macaque monkeys. Adv Neurol 1997;74:45-56.

-27 Chan CS, Shigemoto R, Mercer JN, Surmeier DJ: HCN2 and HCN1 channels govern the regularity of autonomous pacemaking and synaptic resetting in globus pallidus neurons. $\mathrm{J}$ Neurosci 2004;24:9921-9932.

28 Hoover BR, Marshall JF: Population characteristics of preproenkephalin mRNA-containing neurons in the globus pallidus of the rat. Neurosci Lett 1999;265:199-202.

-29 Hoover BR, Marshall JF: Further characterization of preproenkephalin mRNA-containing cells in the rodent globus pallidus. Neuroscience 2002;111:111-125.

30 Voorn P, van de Witte S, Tjon G, Jonker AJ: Expression of enkephalin in pallido-striatal neurons. Ann N Y Acad Sci 1999;877:671675 .

-31 Zaborszky L, Pang K, Somogyi J, Nadasdy Z, Kallo I: The basal forebrain corticopetal system revisited. Ann N Y Acad Sci 1999;877: 339-367.

32 Bengtson CP, Osborne PB: Electrophysiological properties of cholinergic and noncholinergic neurons in the ventral pallidal region of the nucleus basalis in rat brain slices. J Neurophysiol 2000;83:2649-2660.

33 Tkatch T, Baranauskas G, Surmeier DJ: Basal forebrain neurons adjacent to the globus pallidus co-express GABAergic and cholinergic marker mRNAs. Neuroreport 1998;9:19351939.
34 Bernard V, Bolam JP: Subcellular and subsynaptic distribution of the NR1 subunit of the NMDA receptor in the neostriatum and globus pallidus of the rat: co-localization at synapses with the GluR2/3 subunit of the AMPA receptor. Eur J Neurosci 1998;10:3721-3736.

35 Gerfen CR, Young WS 3rd: Distribution of striatonigral and striatopallidal peptidergic neurons in both patch and matrix compartments: an in situ hybridization histochemistry and fluorescent retrograde tracing study. Brain Res 1988;460:161-167.

36 Kawaguchi Y, Wilson CJ, Emson PC: Projection subtypes of rat neostriatal matrix cells revealed by intracellular injection of biocytin. $\mathrm{J}$ Neurosci 1990;10:3421-3438.

- 37 Surmeier DJ, Song WJ, Yan Z: Coordinated expression of dopamine receptors in neostriatal medium spiny neurons. J Neurosci 1996; 16:6579-6591.

38 Falls WM, Park MR, Kitai ST: An intracellular HRP study of the rat globus pallidus. II. Fine structural characteristics and synaptic connections of medially located large GP neurons. J Comp Neurol 1983;221:229-245.

39 Okoyama S, Nakamura Y, Moriizumi T, Kitao $Y$ : Electron microscopic analysis of the synaptic organization of the globus pallidus in the cat. J Comp Neurol 1987;265:323-331.

-40 Chang HT, Wilson CJ, Kitai ST: Single neostriatal efferent axons in the globus pallidus: a light and electron microscopic study. Science 1981;213:915-918

41 Haber SN, Nauta WJ: Ramifications of the globus pallidus in the rat as indicated by patterns of immunohistochemistry. Neuroscience 1983; 9:245-260.

42 Hazrati LN, Parent A: The striatopallidal projection displays a high degree of anatomical specificity in the primate. Brain Res 1992;592: 213-227.

43 Parent A, Hazrati LN, Charara A: The striatopallidal fiber system in primates. Adv Neurol 1997;74:19-29.

44 Difiglia M, Rafols JA: Synaptic organization of the globus pallidus. J Electron Microsc Tech 1988;10:247-263.

45 Fox CA, Rafols JA: The radial fibers in the globus pallidus. J Comp Neurol 1975; 159:177199

46 Fox CA, Rafols JA: The striatal efferents in the globus pallidus and in the substantia nigra. Res Publ Assoc Res Nerv Ment Dis 1976;55:3755.

47 Sugihara I, Wu H, Shinoda Y: Morphology of single olivocerebellar axons labeled with biotinylated dextran amine in the rat. J Comp Neurol 1999;414:131-148.

48 Ramón y Cajal S: Histologie du système nerveux de l'homme et des vertébrés. Paris, Maloine, 1911

49 Eccles JC, Llinas R, Sasaki K: The excitatory synaptic action of climbing fibres on the Purkinje cells of the cerebellum. J Physiol 1966; 182:268-296. 
50 Kita H: Two Pathways between the Cortex and the Basal Ganglia Output Nucleus and the Globus Pallidus. New York, Plenum Press, 1995.

51 Millhouse OE: Pallidal neurons in the rat. J Comp Neurol 1986;254:209-227.

-52 Wilson CJ, Phelan KD: Dual topographic representation of neostriatum in the globus pallidus of rats. Brain Res 1982;243:354-359.

-53 Oorschot DE: Total number of neurons in the neostriatal, pallidal, subthalamic, and substantia nigral nuclei of the rat basal ganglia: a stereological study using the Cavalieri and optical dissector methods. J Comp Neurol 1996;366: 580-599.

- 54 Francois C, Percheron G, Yelnik J, Heyner S: A Golgi analysis of the primate globus pallidus. I. Inconstant processes of large neurons, other neuronal types, and afferent axons. J Comp Neurol 1984;227:182-199.

55 Percheron G, Yelnik J, Francois C: A Golgi analysis of the primate globus pallidus. III. Spatial organization of the striato-pallidal complex. J Comp Neurol 1984;227:214-227.

-56 Park MR, Falls WM, Kitai ST: An intracellular HRP study of the rat globus pallidus. I. Responses and light microscopic analysis. J Comp Neurol 1982;211:284-294.

57 Anderson ME, Horak FB: Influence of the globus pallidus on arm movements in monkeys. III. Timing of movement-related information. J Neurophysiol 1985;54:433-448.

-58 Matsumura M, Tremblay L, Richard H, Filion M: Activity of pallidal neurons in the monkey during dyskinesia induced by injection of bicuculline in the external pallidum. Neuroscience 1995;65:59-70.

- 59 Nambu A, Tokuno H, Hamada I, Kita H, Imanishi M, Akazawa T, Ikeuchi Y, Hasegawa $\mathrm{N}$ : Excitatory cortical inputs to pallidal neurons via the subthalamic nucleus in the monkey. J Neurophysiol 2000;84:289-300.

60 Tremblay L, Filion M, Bedard PJ: Responses of pallidal neurons to striatal stimulation in monkeys with MPTP-induced parkinsonism. Brain Res 1989;498:17-33.

-61 Yoshida S, Nambu A, Jinnai K: The distribution of the globus pallidus neurons with input from various cortical areas in the monkeys. Brain Res 1993;611:170-174.

-62 Nini A, Feingold A, Slovin H, Bergman H: Neurons in the globus pallidus do not show correlated activity in the normal monkey, but phase-locked oscillations appear in the MPTP model of parkinsonism. J Neurophysiol 1995; 74:1800-1805.

63 Kita H, Kitai S: Anatomy and Physiology of the Subthalamic Nucleus: a Driving Force of the Basal Ganglia. New York, Plenum Press, 1987.

-64 Kita H, Kitai ST: Intracellular study of rat globus pallidus neurons: membrane properties and responses to neostriatal, subthalamic and nigral stimulation. Brain Res 1991;564:296305.

65 Surmeier DJ, Mercer JN, Chan CS: Autonomous pacemakers in the basal ganglia: who needs excitatory synapses anyway? Curr Opin Neurobiol 2005;15:312-318.
66 Kita H, Nambu A, Kaneda K, Tachibana Y, Takada M: Role of ionotropic glutamatergic and GABAergic inputs on the firing activity of neurons in the external pallidum in awake monkeys. J Neurophysiol 2004;92:30693084.

67 Magill PJ, Bolam JP, Bevan MD: Dopamine regulates the impact of the cerebral cortex on the subthalamic nucleus-globus pallidus network. Neuroscience 2001;106:313-330.

68 Magill PJ, Sharott A, Bolam JP, Brown P: Brain state-dependency of coherent oscillatory activity in the cerebral cortex and basal ganglia of the rat. J Neurophysiol 2004;92:21222136.

69 Brotchie P, Iansek R, Horne MK: Motor function of the monkey globus pallidus. 2. Cognitive aspects of movement and phasic neuronal activity. Brain 1991;114(Pt 4):1685-1702.

70 Kita H: Responses of globus pallidus neurons to cortical stimulation: intracellular study in the rat. Brain Res 1992;589:84-90.

71 Hassler R: Striatal control of locomotion, intentional actions and of integrating and perceptive activity. J Neurol Sci 1978;36:187224.

-72 Nakanishi H, Hori N, Kastuda N: Neostriatal evoked inhibition and effects of dopamine on globus pallidal neurons in rat slice preparations. Brain Res 1985;358:282-286.

-73 Stanford IM, Cooper AJ: Presynaptic mu and delta opioid receptor modulation of $\mathrm{GABA}_{A}$ IPSCs in the rat globus pallidus in vitro. J Neurosci 1999; 19:4796-4803.

74 Valenti O, Marino MJ, Wittmann M, Lis E, DiLella AG, Kinney GG, Conn PJ: Group III metabotropic glutamate receptor-mediated modulation of the striatopallidal synapse. J Neurosci 2003;23:7218-7226.

75 Shin RM, Masuda M, Miura M, Sano H, Shirasawa $\mathrm{T}$, Song WJ, Kobayashi K, Aosaki T: Dopamine D4 receptor-induced postsynaptic inhibition of GABAergic currents in mouse globus pallidus neurons. J Neurosci 2003;23 11662-11672.

76 Shindou T, Mori A, Kase H, Ichimura M Adenosine $\mathrm{A}_{2 A}$ receptor enhances $\mathrm{GABA}_{4}-\mathrm{me}$ diated IPSCs in the rat globus pallidus. J Physiol 2001:532(Pt 2):423-434

77 Zucker RS, Regehr WG: Short-term synaptic plasticity. Annu Rev Physiol 2002;64:355405 .

78 Terman D, Rubin JE, Yew AC, Wilson CJ: Activity patterns in a model for the subthalamopallidal network of the basal ganglia. J Neurosci 2002;22:2963-2976.

79 Sieghart W: Unraveling the function of $\mathrm{GABA}_{\mathrm{A}}$ receptor subtypes. Trends Pharmacol Sci 2000; 21:411-413.

80 Barnard EA, Skolnick P, Olsen RW, Mohler H, Sieghart W, Biggio G, Braestrup C, Bateson AN, Langer SZ: International Union of Pharmacology. XV. Subtypes of gamma-aminobutyric acidA receptors: classification on the basis of subunit structure and receptor function. Pharmacol Rev 1998;50:291-313.
81 Jones-Davis DM, Macdonald RL: GABAA receptor function and pharmacology in epilepsy and status epilepticus. Curr Opin Pharmacol 2003;3:12-18.

82 Whiting PJ: The GABA-A receptor gene family: new targets for therapeutic intervention. Neurochem Int 1999;34:387-390.

83 Whiting PJ, Bonnert TP, McKernan RM, Farrar S, Le Bourdelles B, Heavens RP, Smith DW, Hewson L, Rigby MR, Sirinathsinghji DJ, Thompson SA, Wafford KA: Molecular and functional diversity of the expanding GABA-A receptor gene family. Ann N Y Acad Sci 1999;868:645-653.

84 Wafford KA: $\mathrm{GABA}_{\mathrm{A}}$ receptor subtypes: any clues to the mechanism of benzodiazepine dependence? Curr Opin Pharmacol 2005;5:4752.

85 Rudolph U, Crestani F, Mohler H: GABA receptor subtypes: dissecting their pharmacological functions. Trends Pharmacol Sci 2001;22: 188-194.

86 Mohler H, Crestani F, Rudolph U: GABA receptor subtypes: a new pharmacology. Curr Opin Pharmacol 2001;1:22-25.

-87 Wisden W, Laurie DJ, Monyer H, Seeburg PH: The distribution of $13 \mathrm{GABA}_{\mathrm{A}}$ receptor subunit mRNAs in the rat brain. I. Telencephalon, diencephalon, mesencephalon. J Neurosci 1992;12:1040-1062.

88 Hartig W, Brauer K, Fritschy JM, Bruckner G, Bigl V: Regional and cellular expression sites of the alpha 1 subunit of $\mathrm{GABA}_{\mathrm{A}}$ receptors in the rat basal forebrain: a cytochemical study with glutamic acid decarboxylase, choline acetyltransferase, calcium-binding proteins and nitric oxide synthase as second markers. Brain Res 1995;692:215-226.

89 Riedel A, Hartig W, Fritschy JM, Bruckner G, Seifert U, Brauer K: Comparison of the rat dorsal and ventral striatopallidal system: a study using the $\mathrm{GABA}_{\mathrm{A}}$-receptor alpha1-subunit and parvalbumin immunolabeling. Exp Brain Res 1998:121:215-221.

90 Waldvogel HJ, Fritschy JM, Mohler H, Faull $\mathrm{RL}: \mathrm{GABA}_{\mathrm{A}}$ receptors in the primate basal ganglia: an autoradiographic and a light and electron microscopic immunohistochemical study of the alpha1 and beta2,3 subunits in the baboon brain. J Comp Neurol 1998;397:297325

-91 Waldvogel HJ, Kubota Y, Fritschy JM, Mohler H, Faull RL: Regional and cellular localisation of $\mathrm{GABA}_{\mathrm{A}}$ receptor subunits in the human basal ganglia: an autoradiographic and immunohistochemical study. J Comp Neurol 1999; 415:313-340.

92 Pirker S, Schwarzer C, Wieselthaler A, Sieghart W, Sperk G: GABA $A_{A}$ receptors: immunocytochemical distribution of 13 subunits in the adult rat brain. Neuroscience 2000;101:815850.

-93 Schwarzer C, Berresheim U, Pirker S, Wieselthaler A, Fuchs K, Sieghart W, Sperk G: Distribution of the major gamma-aminobutyric acid(A) receptor subunits in the basal ganglia and associated limbic brain areas of the adult rat. J Comp Neurol 2001;433:526-549. 
-94 Okada M, Onodera K, Van Renterghem C, 106 De Biasi S, Vitellaro-Zuccarello L, Brecha Sieghart W, Takahashi T: Functional correlation of $\mathrm{GABA}_{\mathrm{A}}$ receptor alpha subunit expression with the properties of IPSCs in the developing thalamus. J Neurosci 2000;20: 2202-2208.

-95 Vicini S, Ferguson C, Prybylowski K, Kralic J, Morrow AL, Homanics GE: GABA receptor alpha1 subunit deletion prevents developmental changes of inhibitory synaptic currents in cerebellar neurons. J Neurosci 2001; 21:3009-3016.

$>96$ Hollrigel GS, Soltesz I: Slow kinetics of miniature IPSCs during early postnatal development in granule cells of the dentate gyrus. J Neurosci 1997; 17:5119-5128.

$\checkmark 97$ Somogyi P, Fritschy JM, Benke D, Roberts JD, Sieghart W: The gamma 2 subunit of the $\mathrm{GABA}_{\mathrm{A}}$ receptor is concentrated in synaptic junctions containing the alpha 1 and beta $2 / 3$ subunits in hippocampus, cerebellum and globus pallidus. Neuropharmacology 1996; 35:1425-1444.

-98 Charara A, Pare JF, Levey AI, Smith Y: Synaptic and extrasynaptic GABA-A and GABA$B$ receptors in the globus pallidus: an electron microscopic immunogold analysis in monkeys. Neuroscience 2005;131:917-933.

$>99$ Sur C, Wafford KA, Reynolds DS, Hadingham KL, Bromidge F, Macaulay A, Collinson N, O’Meara G, Howell O, Newman R, Myers J, Atack JR, Dawson GR, McKernan RM, Whiting PJ, Rosahl TW: Loss of the major $\mathrm{GABA}_{\mathrm{A}}$ receptor subtype in the brain is not lethal in mice. J Neurosci 2001;21:34093418.

$>100$ Radian R, Ottersen OP, Storm-Mathisen J, Castel M, Kanner BI: Immunocytochemical localization of the GABA transporter in rat brain. J Neurosci 1990;10:1319-1330.

101 Ikegaki N, Saito N, Hashima M, Tanaka C: Production of specific antibodies against GABA transporter subtypes (GAT1, GAT2, GAT3) and their application to immunocytochemistry. Brain Res Mol Brain Res 1994;26: 47-54.

102 Itouji A, Sakai N, Tanaka C, Saito N: Neuronal and glial localization of two GABA transporters (GAT1 and GAT3) in the rat cerebellum. Brain Res Mol Brain Res 1996;37: 309-316.

103 Yan XX, Cariaga WA, Ribak CE: Immunoreactivity for GABA plasma membrane transporter, GAT-1, in the developing rat cerebral cortex: transient presence in the somata of neocortical and hippocampal neurons. Brain Res Dev Brain Res 1997;99:1-19.

104 Barakat L, Bordey A: GAT-1 and reversible GABA transport in Bergmann glia in slices. $\mathrm{J}$ Neurophysiol 2002;88:1407-1419.

- 105 Chiu CS, Jensen K, Sokolova I, Wang D, Li M, Deshpande P, Davidson N, Mody I, Quick MW, Quake SR, Lester HA: Number, density, and surface/cytoplasmic distribution of GABA transporters at presynaptic structures of knock-in mice carrying GABA transporter subtype 1-green fluorescent protein fusions. J Neurosci 2002;22:10251-10266.
NC: Immunoreactivity for the GABA transporter- 1 and GABA transporter- 3 is restricted to astrocytes in the rat thalamus: a light and electron microscopic immunolocalization. Neuroscience 1998;83:815-828.

107 Minelli A, De Biasi S, Brecha NC, Zuccarello LV, Conti F: GAT-3, a high-affinity GABA plasma membrane transporter, is localized to astrocytic processes, and it is not confined to the vicinity of GABAergic synapses in the cerebral cortex. J Neurosci 1996;16:62556264.

108 Ribak CE, Tong WM, Brecha NC: Astrocytic processes compensate for the apparent lack of GABA transporters in the axon terminals of cerebellar Purkinje cells. Anat Embryol (Berl) 1996;194:379-390.

109 Ribak CE, Tong WM, Brecha NC: GABA plasma membrane transporters, GAT-1 and GAT-3, display different distributions in the rat hippocampus. J Comp Neurol 1996;367: 595-606.

110 Yasumi M, Sato K, Shimada S, Nishimura M, Tohyama M: Regional distribution of GABA transporter 1 (GAT1) mRNA in the rat brain: comparison with glutamic acid decarboxylase67 (GAD67) mRNA localization. Brain Res Mol Brain Res 1997;44:205-218.

$111 \mathrm{Ng} \mathrm{CH}$, Wang XS, Ong WY: A light and electron microscopic study of the GABA transporter GAT-3 in the monkey basal ganglia and brainstem. J Neurocytol 2000;29:595603.

112 Wang XS, Ong WY: A light and electron microscopic study of GAT-1 in the monkey basal ganglia. J Neurocytol 1999;28:10531061.

113 Durkin MM, Smith KE, Borden LA, Weinshank RL, Branchek TA, Gustafson EL: Localization of messenger RNAs encoding three GABA transporters in rat brain: an in situ hybridization study. Brain Res Mol Brain Res 1995;33:7-21.

114 Suzdak PD, Foged C, Andersen KE: Quantitative autoradiographic characterization of the binding of $\left[{ }^{3} \mathrm{H}\right]$ tiagabine (NNC 05-328) to the GABA uptake carrier. Brain Res 1994; 647:231-241.

115 Fink-Jensen A, Suzdak PD, Swedberg MD, Judge ME, Hansen L, Nielsen PG: The gamma-aminobutyric acid (GABA) uptake inhibitor, tiagabine, increases extracellular brain levels of GABA in awake rats. Eur J Pharmacol 1992;220:197-201.

116 Chiu CS, Brickley S, Jensen K, Southwell A, McKinney S, Cull-Candy S, Mody I, Lester HA: GABA transporter deficiency causes tremor, ataxia, nervousness, and increased GABA-induced tonic conductance in cerebellum. J Neurosci 2005;25:3234-3245.

117 Chen L, Yung WH: Effects of the GABA uptake inhibitor tiagabine in rat globus pallidus. Exp Brain Res 2003;152:263-269.
118 Galvan A, Villalba RM, West SM, Maidment NT, Ackerson LC, Smith Y, Wichmann T: GABAergic modulation of the activity of globus pallidus neurons in primates: in vivo analysis of the functions of GABA receptors and GABA transporters. J Neurophysiol 2005;94:990-1000.

119 Notomi T, Shigemoto R: Immunohistochemical localization of Ih channel subunits, HCN1-4, in the rat brain. J Comp Neurol 2004; 471:241-276.

120 Filion M, Tremblay L: Abnormal spontaneous activity of globus pallidus neurons in monkeys with MPTP-induced parkinsonism. Brain Res 1991;547:142-151.

121 Bergman H, Feingold A, Nini A, Raz A, Slovin H, Abeles M, Vaadia E: Physiological aspects of information processing in the basal ganglia of normal and parkinsonian primates. Trends Neurosci 1998;21:32-38.

122 Raz A, Frechter-Mazar V, Feingold A, Abeles M, Vaadia E, Bergman H: Activity of pallidal and striatal tonically active neurons is correlated in mptp-treated monkeys but not in normal monkeys. J Neurosci 2001;21:RC128.

123 Raz A, Vaadia E, Bergman H: Firing patterns and correlations of spontaneous discharge of pallidal neurons in the normal and the tremulous 1-methyl-4-phenyl-1,2,3,6-tetrahydropyridine vervet model of parkinsonism. J Neurosci 2000;20:8559-8571.

124 Soares J, Kliem MA, Betarbet R, Greenamyre JT, Yamamoto B, Wichmann T: Role of external pallidal segment in primate parkinsonism: comparison of the effects of 1-methyl-4phenyl-1,2,3,6-tetrahydropyridine-induced parkinsonism and lesions of the external pallidal segment. J Neurosci 2004;24:64176426.

125 Magnin M, Morel A, Jeanmonod D: Singleunit analysis of the pallidum, thalamus and subthalamic nucleus in parkinsonian patients. Neuroscience 2000;96:549-564.

126 Filion M: Effects of interruption of the nigrostriatal pathway and of dopaminergic agents on the spontaneous activity of globus pallidus neurons in the awake monkey. Brain Res 1979; 178:425-441.

127 Hutchison WD, Lozano AM, Tasker RR, Lang AE, Dostrovsky JO: Identification and characterization of neurons with tremor-frequency activity in human globus pallidus. Exp Brain Res 1997; 113:557-563.

128 Lozano AM, Hutchison WD, Kiss Z, Tasker RR, Davis K, Dostrovsky JO: Methods for microelectrode-guided posteroventral pallidotomy. J Neurosurg 1996;84:194-202.

129 Taha JM, Favre J, Baumann TK, Burchiel $\mathrm{KJ}$ : Characteristics and somatotopic organization of kinesthetic cells in the globus pallidus of patients with Parkinson's disease. J Neurosurg 1996;85:1005-1012.

130 El-Deredy W, Branston NM, Samuel M, Schrag A, Rothwell JC, Thomas DG, Quinn NP: Firing patterns of pallidal cells in parkinsonian patients correlate with their pre-pallidotomy clinical scores. Neuroreport 2000;11: 3413-3418. 
131 Vitek JL, Hashimoto T, Peoples J, DeLong MR, Bakay RA: Acute stimulation in the external segment of the globus pallidus improves parkinsonian motor signs. Mov Disord 2004;19:907-915.

132 Plenz D, Kital ST: A basal ganglia pacemaker formed by the subthalamic nucleus and external globus pallidus. Nature 1999;400:677682 .

133 Bevan MD, Magill PJ, Hallworth NE, Bolam JP, Wilson CJ: Regulation of the timing and pattern of action potential generation in rat subthalamic neurons in vitro by GABA-A IPSPs. J Neurophysiol 2002;87:1348-1362.

134 Maneuf YP, Mitchell IJ, Crossman AR, Brotchie JM: On the role of enkephalin cotransmission in the GABAergic striatal efferents to the globus pallidus. Exp Neurol 1994; 125:65-71.

135 Kato M, Kimura M: Effects of reversible blockade of basal ganglia on a voluntary arm movement. J Neurophysiol 1992;68:15161534.

136 Tremblay L, Filion M: Behavioral and neuronal effects of GABA agonist and antagonist injected locally in the globus pallidus of intact monkeys. Soc Neurosci Abstr 1990.

137 Vernier P, Julien JF, Rataboul P, Fourrier O, Feuerstein C, Mallet J: Similar time course changes in striatal levels of glutamic acid decarboxylase and proenkephalin mRNA following dopaminergic deafferentation in the rat. J Neurochem 1988;51:1375-1380.

138 Ingham CA, Hood SH, Mijnster MJ, Baldock RA, Arbuthnott GW: Plasticity of striatopallidal terminals following unilateral lesion of the dopaminergic nigrostriatal pathway: a morphological study. Exp Brain Res 1997; 116:39-49.
139 Lindefors N, Brene S, Herrera-Marschitz M, Persson H: Region specific regulation of glutamic acid decarboxylase mRNA expression by dopamine neurons in rat brain. Exp Brain Res 1989;77:611-620.

140 Lindefors N, Brodin E, Tossman U, Segovia $\mathrm{J}$, Ungerstedt U: Tissue levels and in vivo release of tachykinins and GABA in striatum and substantia nigra of rat brain after unilateral striatal dopamine denervation. Exp Brain Res 1989;74:527-534.

141 Pan HS, Penney JB, Young AB: Gamma-aminobutyric acid and benzodiazepine receptor changes induced by unilateral 6-hydroxydopamine lesions of the medial forebrain bundle. J Neurochem 1985;45:1396-1404.

142 Griffiths MR, Mitchell IJ, Cooper AJ: Phencyclidine induces D-1 dopamine receptor mediated Fos-like immunoreactivity in discretely localised populations of striatopallidal and striatoentopeduncular neurons in the rat. Brain Res 1999;821:177-189.

143 Robertson RG, Clarke CA, Boyce S, Sambrook MA, Crossman AR: The role of striatopallidal neurones utilizing gamma-aminobutyric acid in the pathophysiology of MPTP-induced parkinsonism in the primate: evidence from $[3 \mathrm{H}]$ flunitrazepam autoradiography. Brain Res 1990;531:95-104.

144 Calon F, Goulet M, Blanchet PJ, Martel JC, Piercey MF, Bedard PJ, Di Paolo T: Levodopa or D2 agonist induced dyskinesia in MPTP monkeys: correlation with changes in dopamine and $\mathrm{GABA}_{\mathrm{A}}$ receptors in the striatopallidal complex. Brain Res 1995;680:43-52.
145 Caruncho HJ, Liste I, Rozas G, Lopez-Martin E, Guerra MJ, Labandeira-Garcia JL: Time course of striatal, pallidal and thalamic alpha 1 , alpha 2 and beta $2 / 3 \mathrm{GABA}_{\mathrm{A}}$ receptor subunit changes induced by unilateral 6-OHDA lesion of the nigrostriatal pathway. Brain Res Mol Brain Res 1997;48:243-250.

146 Chadha A, Howell O, Atack JR, Sur C, Duty $\mathrm{S}$ : Changes in $[3 \mathrm{H}]$ zolpidem and $[3 \mathrm{H}] \mathrm{Ro} 15$ 1788 binding in rat globus pallidus and substantia nigra pars reticulata following a nigrostriatal tract lesion. Brain Res 2000;862: 280-283.

147 Chadha A, Dawson LG, Jenner PG, Duty S: Effect of unilateral 6-hydroxydopamine lesions of the nigrostriatal pathway on $\mathrm{GABA}_{\mathrm{A}}$ receptor subunit gene expression in the rodent basal ganglia and thalamus. Neuroscience 2000;95:119-126.

148 Arbuthnott GW: Spontaneous activity of single units in the striatum after unilateral destruction of the dopamine input. J Physiol 1974;239:121P-122P.

149 Arbuthnott GW, Brown JR, Kapoor V, Whale D: Presynaptic Actions of Dopamine in the Neostriatum. New York, Plenum Press, 1984.

150 Schultz W, Ungerstedt U: Short-term increase and long-term reversion of striatal cell activity after degeneration of the nigrostriatal dopamine system. Exp Brain Res 1978;33: 159-171.

151 Tseng KY, Kasanetz F, Kargieman L, Riquelme LA, Murer MG: Cortical slow oscillatory activity is reflected in the membrane potential and spike trains of striatal neurons in rats with chronic nigrostriatal lesions. J Neurosci 2001;21:6430-6439. 